\title{
Cognitive Structures and Misconceptions with Thematic Framework: The Case of Chemical Bonding
}

\begin{tabular}{ccc}
\hline Article Type & Received Date & Accepted Date \\
Research & 1.10 .2018 & 12.07 .2019 \\
\hline
\end{tabular}

\section{Şenol Şen* $\quad$ Lütfiye Varoğlu** Ayhan Yılmaz ${ }^{* * *}$}

\begin{abstract}
This study aims to investigate undergraduate students' cognitive structures and determinate misconceptions about chemical bonding phenomena. On the other hand, the study achieves to recommend an alternative technique for the evaluation of Word Associations Tests (WAT). The study was carried out with the participation of first year studens; 141 from engineering faculty and 73 from medical sciences faculty of a foundation university in the spring semester of 2017-2018 academic year. WAT about chemical bonds prepared by the researchers was used as a data collection tool. Content analysis were used to analyze the data. The students' responds to the key words given to them were divided into themes and cut-off technique was used according to the themes distinguished. In this context, students' cognitive structures related to chemical bonds were determined within the framework of themes. It has been determined that the students' WAT results regarding to chemical bonding, which supported with concept maps within the framework of the themes, provides convenience in determining the misconceptions because of reflects the concepts and the relationships between the concepts more clearly. In consequence, it is suggested that the new technique of evaluation recommended could be used in prospective studies.
\end{abstract}

Keywords: Chemical bonds, misconceptions, undergraduate students, word association test.

\footnotetext{
${ }^{*}$ Corresponding Author: Assoc. Prof. Dr., Hacettepe University, Faculty of Education, Department of Mathematics and Science Education, Division of Chemistry Education, Ankara, Turkey. E-mail: schenolschen@ gmail.com, http://orcid.org/0000-00033831-3953

** PhD student, European University of Lefke, Faculty of Pharmacy, Lefke, Northern Cyprus. E-mail: 1varoglu@eul.edu.tr, https://orcid.org/0000-0003-2595-5746

${ }_{* * *}$ Prof. Dr., Hacettepe University, Faculty of Education, Department of Mathematics and Science Education, Division of Chemistry Education, Ankara, Turkey. E-mail:ayhany@ hacettepe.edu.tr, http://orcid.org/0000-0003-4252-5510
} 


\title{
Tematik Bir Çerçeveden Bilişsel Yapılar ve Kavram Yanılgıları: Kimyasal Bağlar Örneği
}

\begin{tabular}{|c|c|c|}
\hline $\begin{array}{l}\text { Makale Türü } \\
\text { Araştırma }\end{array}$ & $\begin{array}{c}\text { Başvuru Tarihi } \\
1.10 .2018 \\
\end{array}$ & $\begin{array}{c}\text { Kabul Tarihi } \\
12.07 .2019 \\
\end{array}$ \\
\hline Şenol Şen* & Lütfiye Varoğlu** & Ayhan Yilmaz ${ }^{* * *}$ \\
\hline
\end{tabular}

\begin{abstract}
Bu çalışmanın amacı, lisans öğrencilerinin kimyasal bağ fenomeni ile ilgili bilişsel yapılarının incelenmesi ve kavram yanılgılarının belirlenmesidir. Bunun yanında çalışma kelime ilişkilendirme testlerinin (KIT) değerlendirilmesi için alternatif bir teknik önermeyi de hedeflemektedir. Çalışma, 2017-2018 bahar döneminde bir vakıf üniversitesinin, 141 mühendislik fakültesi ve 73 sağlık bilimleri fakültesi öğrencisi ile yürütülmüştür. Veri toplama aracı olarak araştırmacılar tarafindan hazırlanmış, kimyasal bağlar konusu ile ilgili kelime ilişkilendirme testi kullanılmıştır. Verilerin analizinde içerik analizi kullanılmıştır. Öğrencilerin bilişsel yapılarının ve kavram yanılgılarııın ortaya çıkartılmasında, verilen anahtar kelimelere ilişkin öğrenciler tarafindan verilen yanıtlar, temalar oluşturularak gruplandırılmış ve KIT değerlendirilmesi için bu tematik çerçeveye göre kesme yöntemi kullanılmıştır. Bu bağlamda öğrencilerin kimyasal bağlar konusu ile ilgili bilişsel yapıları temalar çerçevesinde belirlenmiştir. Öğrencilerin kimyasal bağlar konusu ile ilgili KIT sonuçlarının belirlenen temalar çerçevesinde kavram haritalarıyla desteklenmesi, kavramları ve kavramlar arası ilişkileri daha net bir şekilde yansıttı̆̆ı için kavram yanılgılarının belirlenmesinde kolaylık sağladığı belirlenmiştir. Çalışma sonucunda, KIT için sunulan yeni değerlendirme tekniğinin diğer araştırmalarda da kullanılabileceği düşünülmektedir.
\end{abstract}

Anahtar Sözcükler: kavram yanılgısı, kelime ilişkilendirme testi, kimyasal bağlar, üniversite öğrencileri.

\footnotetext{
** Sorumlu Yazar: Doç. Dr., Hacettepe Üniversitesi, Eğitim Fakültesi, Matematik ve Fen Bilimleri Eğitimi Bölümü, Kimya Eğitimi Anabilim Dalı, Ankara, Türkiye. E-posta: schenolschen@ gmail.com, http://orcid.org/0000-0003-3831-3953

*** Doktora Öğrencisi, Lefke Avrupa Üniversitesi, Eczacılık Fakültesi, Lefke, KKTC. E-posta: 1varoglu@eul.edu.tr, https://orcid.org/0000-0003-2595-5746

*** Prof. Dr., Hacettepe Üniversitesi, Eğitim Fakültesi, Matematik ve Fen Bilimleri Eğitimi Bölümü, Kimya Eğitimi Anabilim Dalı, Ankara, Türkiye. E-posta: ayhany@ hacettepe.edu.tr, http://orcid.org/0000-0003-4252-5510
} 


\section{Introduction}

It is pointed out in studies concerning science education that students have various misconceptions due to the fact that some subjects and concepts of chemistry are abstract (Birk \& Kurtz,1999; Ghalkhani \& Mirzaei, 2018; Hackling \& Garnett, 1985; Harrison \& Treagust, 2000; Peterson \& Treagust, 1989; Stavy, 1991b; Taber, 1994; 1997). Those concepts are resistant to being changed and developed in positive ways, since they have integrity in themselves and since they receive support from learners' daily life experience (Driver, 1989). As a result, if a student has misunderstanding about a concept, will also has problems in learning the concepts associated with it. Therefore, the structures in students' minds that different from the definitions made by scientists should firstly be revealed and levels of understanding should be determined to attain conceptual change. For this reason, researchers have developed various methods and instruments to uncover individuals' cognitive structures in the best way. Concept maps (Novak \& Gowin, 1984), predict-observe-explain technique (POE) (White \& Gunstone, 1992), interviews (Osborne \& Cosgrove, 1983) and V diagrams (Novak \& Gowin, 1984) may give as examples for such methods and instruments.

Several studies on misconceptions are available in the literature for science education (Thompson \& Logue, 2006; Treagust, 1988). It was found that, those studies dealt with misconceptions about the matter and its' properties (Stavy, 1991a), atoms (Griffiths \& Preston, 1992), the mole concept (Staver \& Lumpe, 1995), chemical change (Geban \& Bayır, 2000), chemical reactions (Chandrasegaran, Treagust, \& Mocerino, 2007), chemical equilibrium and kinetics (Hackling \& Garnett, 1985), gases (Lin, Cheng, \& Lawrenz, 2000), solutions (Fensham, 1987) and, acids and bases (Hand, 1989). "Chemical Bonds" is a topic of chemistry that students have difficulty and have misconceptions (Tsaparlis, Pappa, \& Byers, 2018). This is because, there are also many studies concerning the misconceptions about chemical bonds, which is the research object for the current study (Birk \& Kurtz, 1999; Harrison \& Treagust, 2000; Perez et al., 2017; Şen \& Yılmaz; 2017; Taber, 1994; 1997; Tsaparlis, Pappa, \& Byers, 2018). Besides, many studies with differing samples, data collection tools and purposes were conducted. Perez et al. (2017), for instance, analyzed high school and university students' misconceptions about chemical bonding comparatively. Taber, Tsaparlis and Nakipoğlu (2012) investigated the concepts of students have about chemical bonding in $\mathrm{NaCl}$ through a diagnostic test. Luxford and Bretz (2014) interviewed high school and undergraduate students attending general chemistry classes to investigate their misconceptions about covalent and ionic bonding. Şen and Yilmaz (2013) researched prospective chemistry teachers' misconceptions through concept maps and lotus flower technique. Atabek Yigit (2016) analyzed undergraduate students' cognitive structures about the topics of basic chemistry, including the concepts of chemical bond, atom and compound through the word association test.

Word association tests (WAT) are a technique used to reveal students' cognitive structures (Shavelson, 1973; Johnstone \& Moynihan, 1985; Cachapuz \& Maskill, 1987; Bahar, Johnstone, \& Sutcliffe, 1999). Bahar and Özatlı (2003) state that WATs are useful since they are easy to prepare and since they can be implemented in a short time. The researchers also say that they can be used both as a diagnosis and as a conceptual change strategy. WAT is a technique which is used to reveal the concepts and the associations between concepts in students' minds, also can be used at the beginning and/or end of the learning-teaching process for identification purposes in determining readiness and for diagnostic purposes in monitoring conceptual change and development (Hastürk, 2017). Studies in the literature also point out that WAT is a technique usable in determining prior knowledge and in evaluating teaching as a pre-test and post-test, or in determining misconceptions (Ercan, Taşdere, \& Ercan, 2010; Demircioğlu, Vural, \& Demircioğlu, 2012; Derman \& Eilks, 2016; Nakiboglu, 2008).

WAT, an alternative technique for evaluation, is a widely used instrument since it is easy and practical to use. Various studies using different techniques in scoring WATs are available in the literature (Stewart, 1979; Johnstone \& Moynihan, 1985; Bahar et al., 1999; Nakiboğlu, 2008). Bahar et al. (1999), proposed cut-off technique to form concept maps revealing students' cognitive structures by preparing of frequency tables indicating the number of repetitions of response words to key words in WAT analysis. Review of literature shows that studies concerning the evaluation of WATs by mapping in cut-off technique are available in differing fields (Bahar et al., 1999; Gok Colak \& Tugluk, 2017; Preece, 1976; Önal, 2017; Shavelson, 1974; Tokcan, 2017; Yucel \& Ozkan, 2015). Yet, there are also 
studies doing different WAT analyses in the literature. For example, Garskoff and Houston (1963) derived relatedness coefficient to define the relationship between two words, the higher the level of relation approaches a value of 1 and approaches a value of 0 for lower relation.- Bahar et al. (1999) used cut-off technique along with Garskoff and Houston's relatedness coefficients in the analysis of WATs. On the other hand, Bingol (2017) evaluated WAT used in relation to water pollution through content analysis, distinguished categories and thus revealed students' cognitive structures related to the subject. Nakiboğlu (2008) recommended a new technique of mapping claiming that mapping by using frequencies and related coefficients had restrictions in WAT analysis.

Based on the idea that WATs are an effective technique in determining cognitive structures, misconceptions and conceptual changes, this study aims to determine cognitive structures and misconceptions, and for this purpose, study recommend an alternative technique for WAT evaluation.. The objective is to determine students' cognitive structures more easily and to determine misconceptions through the new technique. The fact that preparing frequency tables is time consuming in WATs and that concept maps reflecting students' cognitive structures are complex restricts the implementation of those tests. This study is significant in that it contributes to assessing WATs more easily and to determining misconceptions. Primarily frequency table was prepared in relation to the key words in assessing WATs, and themes were distinguished with the given statements based on this. This study is important in that students' cognitive structures and misconceptions about chemical bonds are revealed with the help of cut-off point technique and in that the technique (cut-off) is employed according to categories. Setting out from this, the research problems for the study given below:

1) What is the frequency of undergraduate first year students' responses to WAT about chemical bonds according to the themes?

2) How is the distribution of the students according to the themes; bond, electron, property and example distinguished with WAT?

3) How are the cognitive structures and misconceptions of first year students about chemical bonds, according to the themes distinguished with WAT?

\section{Method}

\section{Research Design}

The case study was used as a research method. Case studies provide rich explanatory information about a case by facilitating the in-depth investigation of the subject of research (Patton, 1990; Y1ldirım \& Şimşek, 2011).

\section{Study Group}

The study was carried out through the General Chemistry I compulsory course in the spring semester of 2017-2018 academic year. The participants of the study were 214 first year undergraduate students; 73 of whom from medical sciences faculty and 141 of whom from engineering faculty in a foundation university. The duration of the study was 3 lecture hours in a week and, 3 weeks totally. The participants were briefed on tree weeks (tree hours in a week) matter and measurements, structure of atoms and the periodic table, and chemical bonding topics by the lecturer, and the data collected during the briefing on chemical bonding topic. All students that were taking the compulsory course participitaded voluntary to the study, yet the students that all attend the course evaluated.

\section{Research Instruments and Procedures}

\section{Word Association Test}

The subject of the study is about "Chemical Bonding". A WAT involving the key words "ionic bond", "covalent bond", "metallic bond" and "coordinate covalent bond" was used so as to reveal students' cognitive structures and misconceptions. Considering the fact that the students had not been informed of WAT, explanations were made about the WAT, and during the application the students were asked to write down the concepts coming into their mind in relation to the key concept within 30 seconds. The WATs about different subjects were conducted before the application. 


\section{Data Analysis}

Students' responses to the key concepts in the WAT analyzed through the content analysis. Content analysis is a method which is based on the logical arrangement of the collected data according to the concepts emerging from the conceptualization of the data and which aims to reach the concepts and associations capable of explaining the collected data by distinguishing themes (Yıldırım \& Şimşek, 2011). The data were analyzed at two stages in this study. At first stage, the frequency was prepared from the students' responses to the key words. At second stage, the responses were divided into themes related to the subject according to the frequency table. A graphic designer draw the cognitive structures.

In accordance with the first research question, students' responses to the key words through the themes distinguished with the WAT and the frequencies were determined. In addition to that, medical sciences faculty and engineering faculty students' cognitive structures about chemical bonds were also shown in Figure 1. The participants' responses to the key words were divided into the themes of 1) bond, 2) electron, 3) property and 4) example. Thus, the participants' cognitive structures were analyzed belong to four themes.

In terms of bond theme, Figure 1 shows that the majority of the students' state that ionic bonds, covalent bonds metallic bonds and coordinate covalent bonds represent the types of chemical bonding. Although most of the students said that ionic bonds were formed through electron transfer $(\mathrm{f}=55)$ between metals and non-metals ( $\mathrm{f}=66$ ) that covalent bonds were formed between non-metals and nonmetals ( $\mathrm{f}=65$ ) and that metallic bonds were formed between metals $(\mathrm{f}=79)$; two students thought that coordinate covalent bonds were a type of covalent bonding and ten students thought that it occurred between two non-metals. Besides, a student had the misconception that ionic bonds occurred between two non-metals $(\mathrm{f}=1)$ and two students had the misconception that covalent bonds occurred between nonmetal and metal $(\mathrm{f}=2)$.

In terms of electron theme, the majority of the students (Figure 1) say that only ionic bonds were formed between anions and cations $(\mathrm{f}=40)$. Accordingly, a minority of the students can associate ionic bond and valance orbital ( $\mathrm{f}=1)$, doublet $(\mathrm{f}=3)$, octet $(\mathrm{f}=8)$, and such bonding the metal gives electron $(\mathrm{f}=2)$. In a similar way, only a few of the students can state the relations between covalent bond and ion pairs of electrons ( $\mathrm{f}=9$ ) and between octet $(\mathrm{f}=8)$ and doublet $(\mathrm{f}=3)$. On relating a student's statement of dipole $(f=1)$ for covalent bonds to the theme of property, statement of polar-apolar relation just by six students is not surprising. In a similar way, setting out from the fact that only a few students made statements about metallic bonds and coordinate covalent bonds in relation to the theme of electron, it may be said that learning for the types of bonding and electrons is inadequate.

According to the students' responses to compounds forming with ionic bonds in terms of the theme of properties (see Figure 1), the fact that only few students set up associations such as salt ( $\mathrm{f}=5$ ), crystalline structure $(\mathrm{f}=2)$, high boiling point $(\mathrm{f}=6)$ and ionic compound $(\mathrm{f}=10)$ demonstrate that students are not at the desired level. Besides, the fact that 17 students described the interactions in this type of bond as strong $(\mathrm{f}=17)$ but two students described as weak $(\mathrm{f}=2)$ emerge as a misconception. It was found in the theme of properties for compounds formed by covalent bonds that only one student stated that it did not conduct electricity when dissolved in water $(\mathrm{f}=1)$ while one student stated that it conducted heat and electricity $(\mathrm{f}=1)$ and had a misconception. In a similar way, 11 students described the interaction as strong $(\mathrm{f}=11)$ whereas nine students described it as weak $(\mathrm{f}=9)$ - which indicated that the students had confusion in this respect. In addition to that, twenty students described the interaction in metallic bonds as strong $(\mathrm{f}=20)$ while one student described it as weak $(\mathrm{f}=1)$, and six students described the interaction in coordinate covalent bonds as weak $(f=6)$ while seven students described it as strong $(f=7)$. Besides, the fact that relations such as metallic bond and alloy $(\mathrm{f}=1)$, coordinate covalent bonds and low boiling point $(\mathrm{f}=1)$ and molecular compounds $(\mathrm{f}=4)$ were set up only by a few students indicated that students had misunderstanding in this respect. 


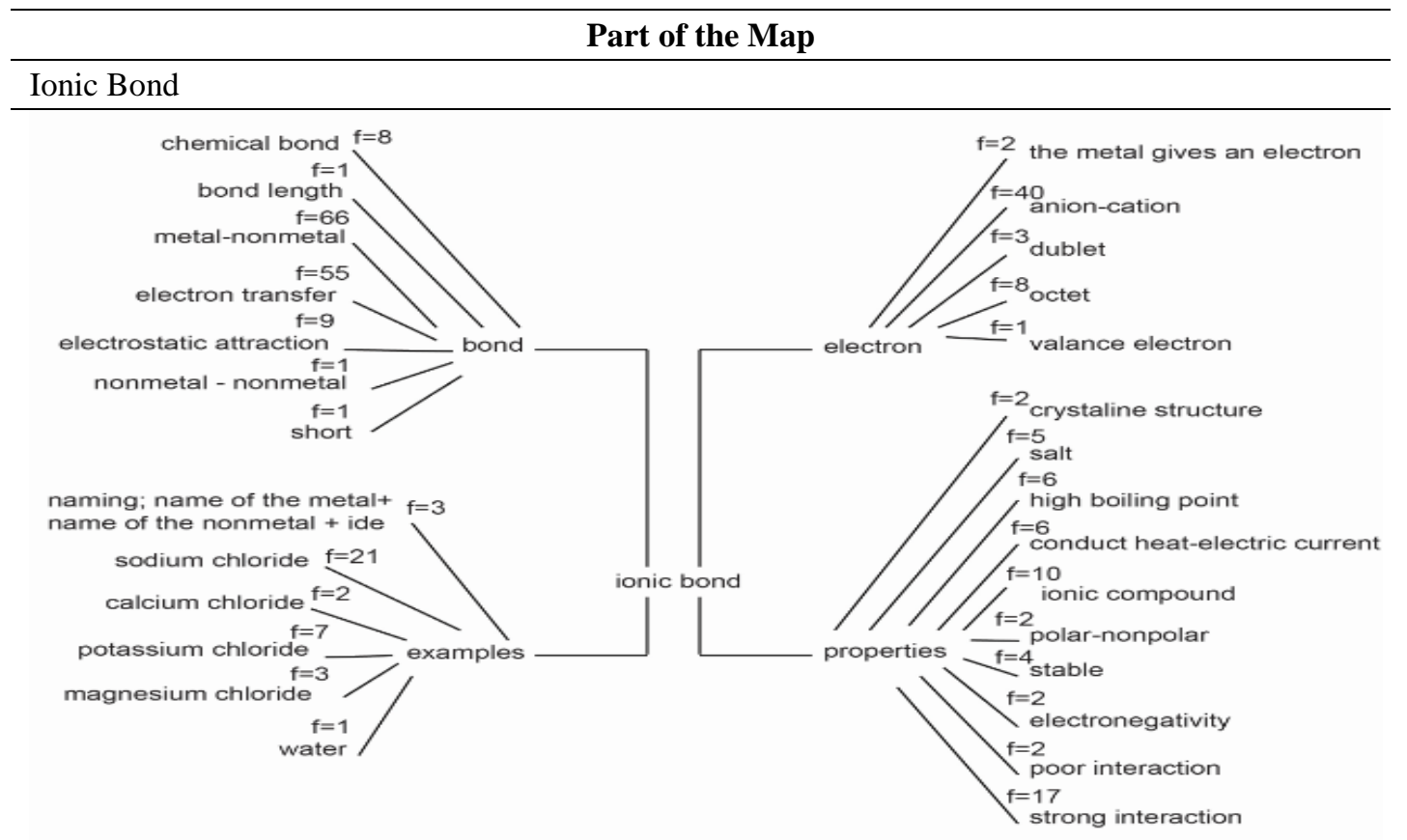

\section{Covalent Bond}

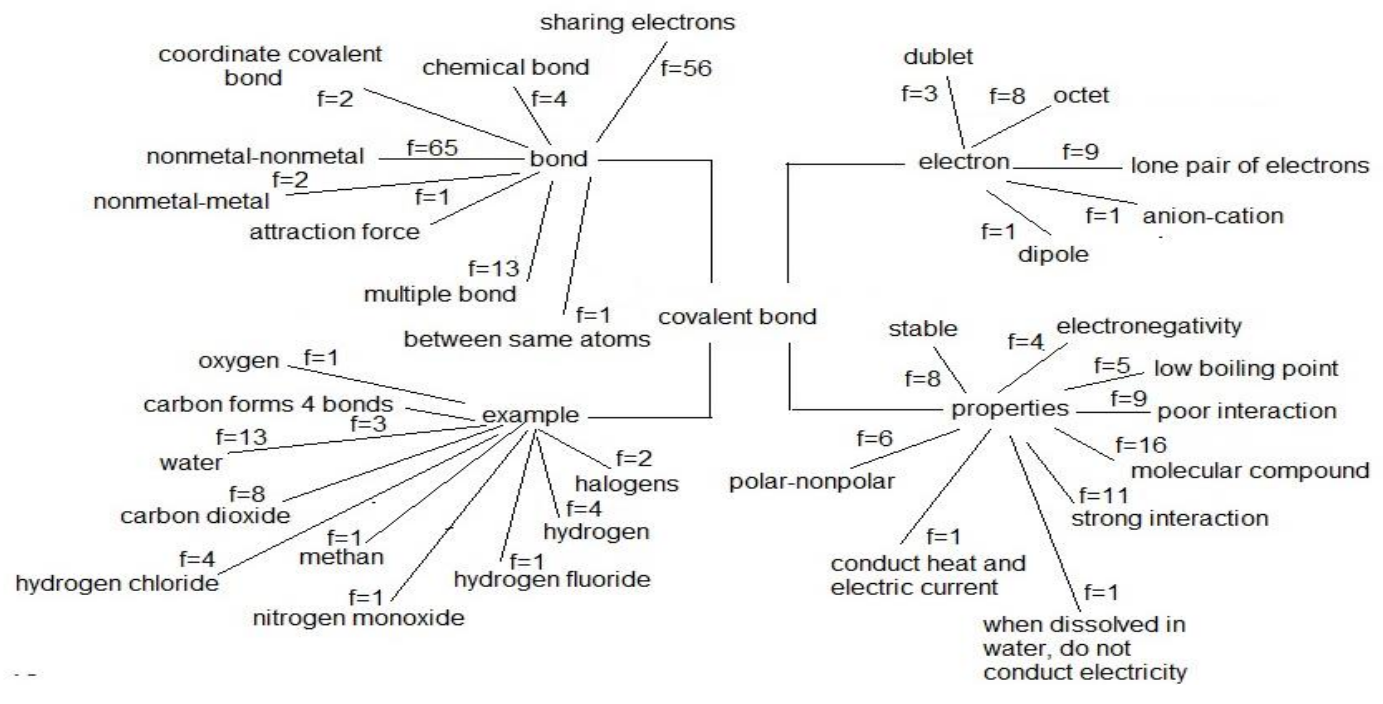

\section{Metallic Bond}

Figure 1. Students' cognitive structures related to chemical bonding

According to the statements collected in the theme of example (Figure 1), few students were found to be able to give examples for these types of bonding. The fact that the students gave the most number of examples for ionic bonds showed that their learning in especially other types of bonding was lower than the adequate level. While only three students could tell how to name the compound which was to occur with ionic bond ( $\mathrm{f}=3$ ), 21 students gave the example of sodium chloride ( $\mathrm{f}=21$ ) for ionic bonds. A students' expression the type of bonding in water as ionic bonding emerges as a misconception. Students' distribution according to the themes of bond, electron, property and example, which were determined according to the results of WAT, was analyzed below in accordance with the second research question. 


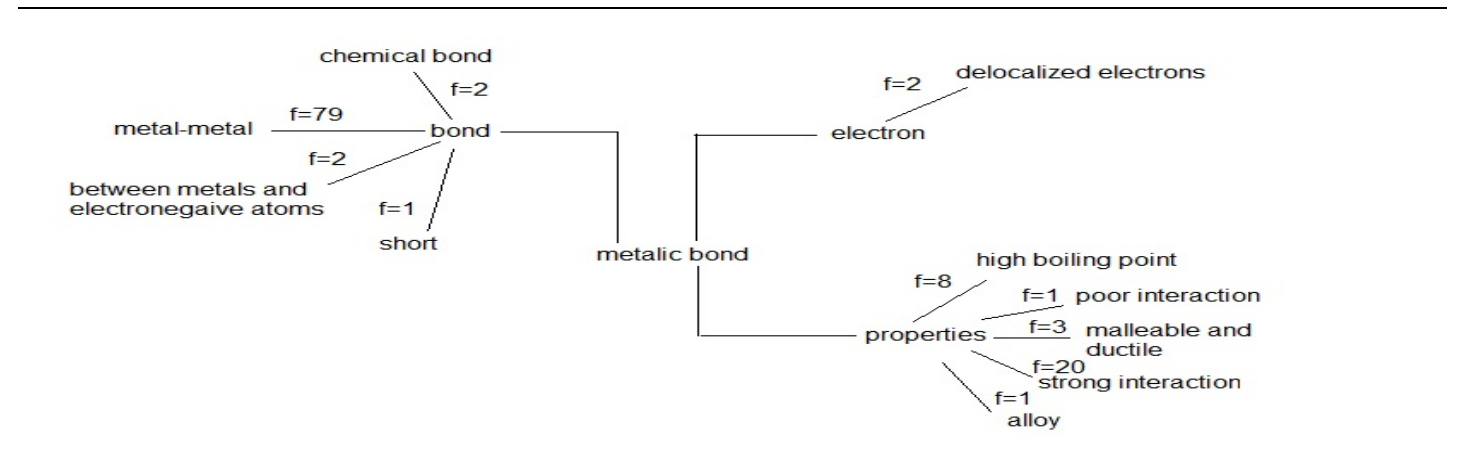

\section{Coordinate Covalent Bond}
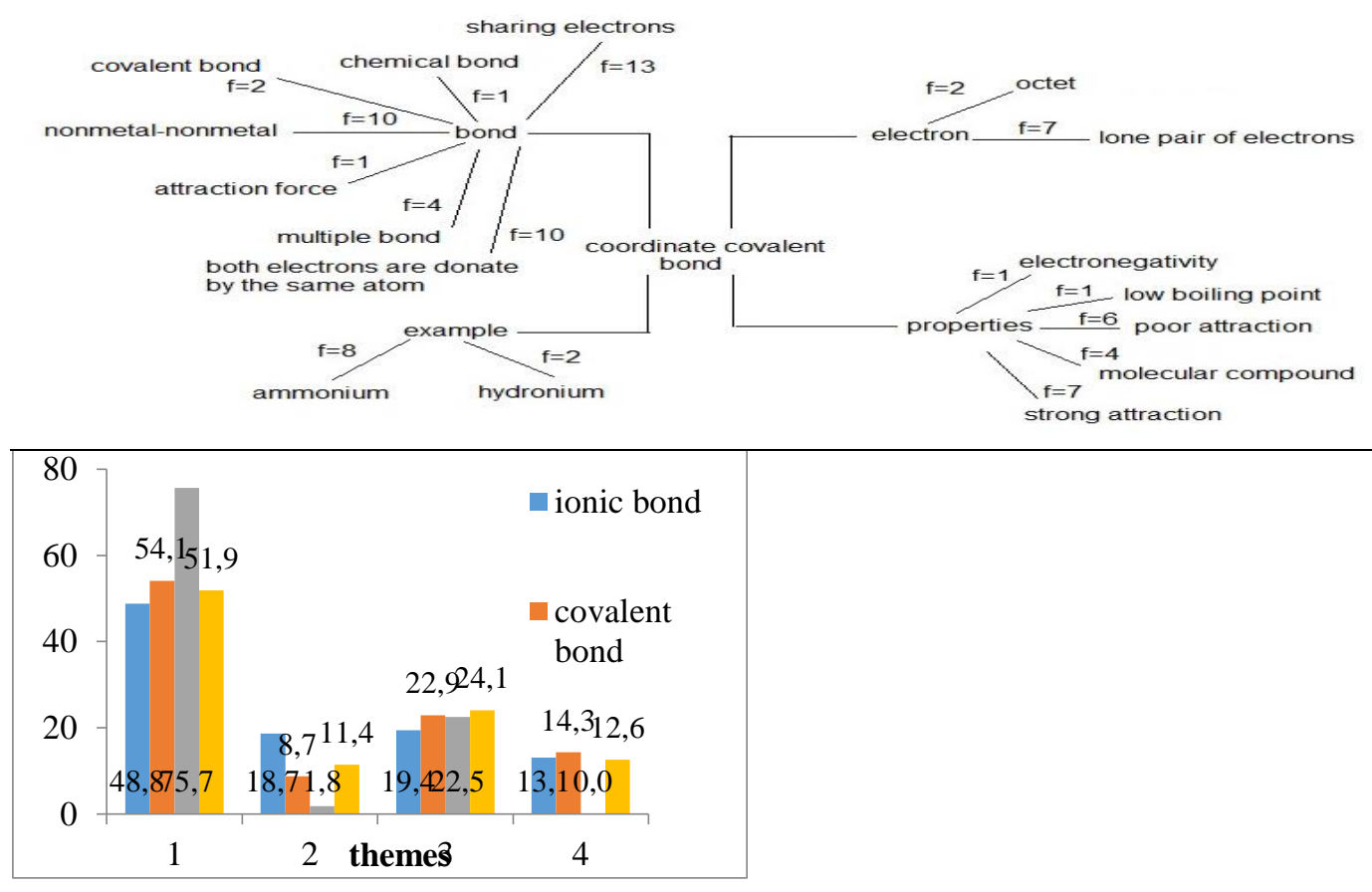

Figure 2. Students' distribution according to their responses to the key words

Figure 2 shows the students' responses to the keywords according to the themes. The students mostly gave the response in the theme of bond (the first theme) to all the key words. On the other hand, they gave the fewest number of responses to the keywords of "ionic bond" and "metallic bond" in the theme of example (the fourth theme), and they also gave the lowest number of responses to the keywords of "covalent bond" and "coordinate covalent bond" in the theme of electron (the second theme). In addition to that, it was also found that they gave the highest rate of responses to the keyword of "metallic bond" (75.7\%) in the first theme but none of them (the lowest rate) gave responses in the fourth theme. Based on these findings, it may be said that the students gave the highest number of responses to the keywords in the theme of bond. The students were found not to have any given examples for the keyword of metallic bond.

Bahar et al. (1999) suggested cut-off technique, which predicted that students' cognitive structures became more and more complicated from high frequencies to low frequencies in WAT assessment. The emergence of complex concept networks is the most important factor making assessment difficult in using the technique. Setting out from this fact, cut-off technique was used by dividing the frequency table into themes and thus efforts were made to reflect students' cognitive structures in a simpler way. The students' cognitive structures and misconceptions were analyzed in terms of themes distinguished according to the results of WAT in line with the third research problem. 


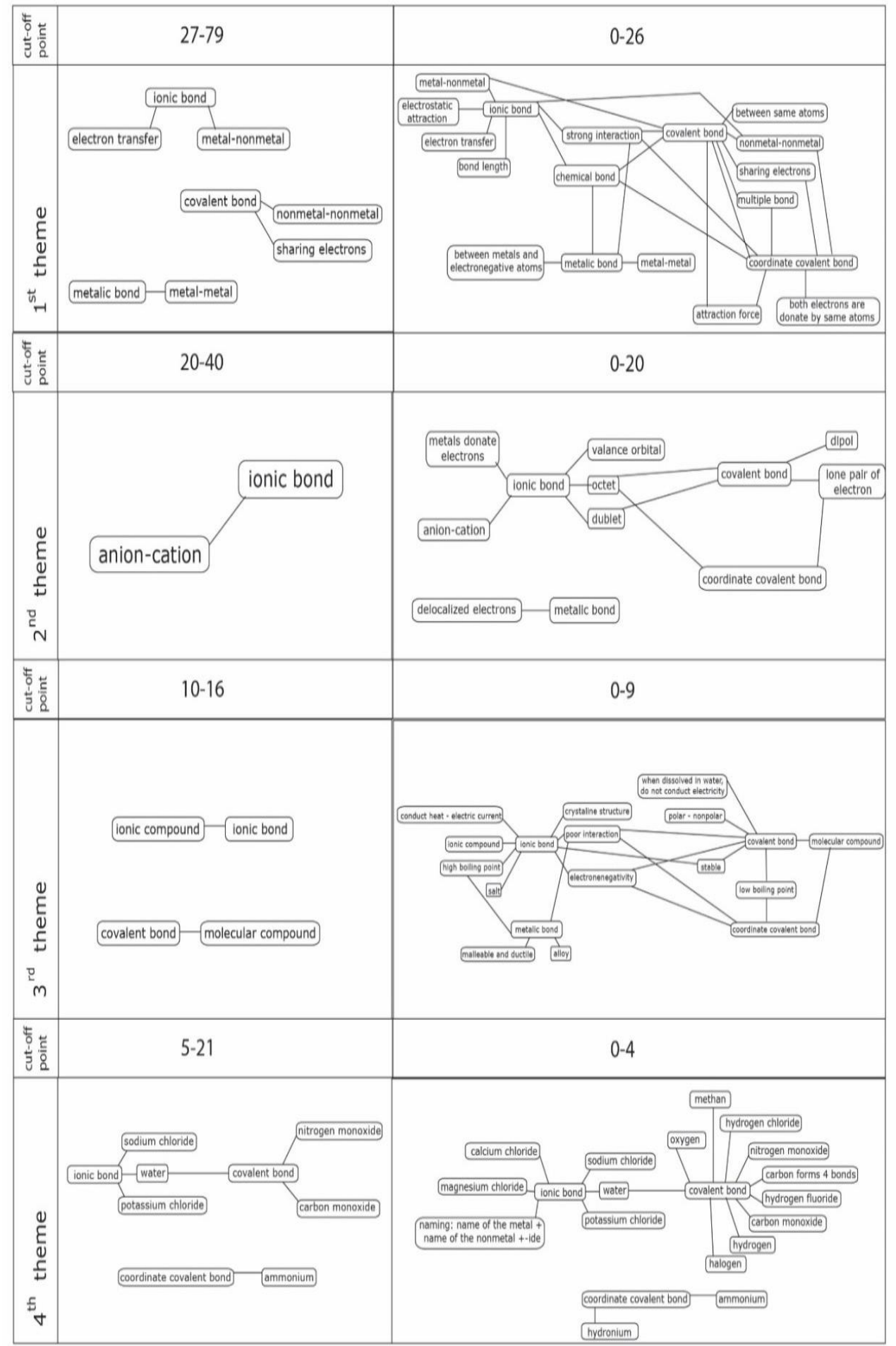

Figure 3. Cognitive structures of the students through the themes

Figure 3 demonstrates the cognitive structures of students determined in cut-off technique. The frequencies for the themes were divided into two levels as high and low. Accordingly, it is remarkable that misconceptions are available in students at low frequency level. 
First theme: It was found in relation to the theme of bond that the students in the group of 27-29 cut-off point could only set up associations about ionic bonds, covalent bonds and metallic bonds. Also, they did not make any statements about coordinate covalent bonds. The students in the group of 0-26 cut-off point, however, could set up more detailed associations about the four types of bonds. Besides, they were also found to definite relation between covalent bond and metal-nonmetals which is misconception.

Second theme: In relation to the theme of electron, the students in the group of 20-40 cut-off point made statements about anion-cation relation but they could not set up any associations about the other key concepts. The students in the group of 0-20 cut-off point talked only about octet and lone pair of electron in relation to coordinate covalent bond; about relations between valance orbital and ionic bonds only, which indicated that they had learnt the rule of octet inadequately. Apart from that, they gave only the response of delocalized electron for the key concept of metallic bond belong to the theme of electron but they did not give any responses about the ideas that metal atoms had more electrons in their external orbitals in metallic bonding or that bonding was based on the principle sharing lone pairs of electrons by displacing them. These also show that students have inadequate knowledge about the subject.

Third theme: In the theme of property, the students in the group of 10-16 cut-off point said that ionic compounds were formed by ionic bonds and that molecular compounds were formed by covalent bonds. As to the students in the group of 0-4 cut-off point, although more developed concept maps were obtained in relation to such properties as the conductivity of compounds formed through chemical bonds, their structure, stability and boiling point; the having small number of students in this group indicated that they lack knowledge in this respect. Weak statement of interaction for all types of bonding stands as a misconception in front of us.

Fourth theme: The theme of example, involves the given examples by for the types of chemical bonds. Accordingly, it was found that the students in the group of 5-21 cut-off point gave sodium chloride and potassium chloride for ionic bonds, nitrogen monoxide and carbon monoxide for covalent bonds and ammonium for coordinate covalent bonds as basic examples. Besides, example of water for ionic bonds was detected as a misconception. The students in the group of 0-4 cut-off point diversified the examples for these three types of bonds. Additionally, they gave halogens as examples for covalent bonds and they mentioned the rule for naming ionic compounds. The students' failure to exemplify metallic bonds indicated that they had inadequate knowledge about chemical bonds. Analyzing students' cognitive structures and their misconceptions according to themes enabled us to perform more detailed analyses and thus to determine their comprehension and misconceptions more clearly.

\section{Discussion, Conclusion and Recommendations}

Techniques to evaluate students' cognitive structures has become into prominence recently. This study aimed to determine cognitive structures and misconceptions by recommending a new technique to be used in WAT evaluation. Accordingly, students' responses to WAT are divided into themes and used in forming concept maps reflecting students' cognitive structures according to the response word frequencies and according to the cut-off technique which recommended by Bahar et al. (1999). It is thought that the concept maps created in this way are simpler; therefore, they can be used in determining misconceptions by analyzing them more easily.

Summarizing students' responses to WAT test by means of concept maps is a technique which has been used (Karakuş \& Karakuş, 2017). This study divided students' responses to the themes before forming concept maps by using cut-off technique. In this way, simpler concept maps were created and misconceptions were determined more easily.

Almost everything in chemistry is built upon particles which cannot be macroscopically observed and on their interactions. When compared with perceptual thinking which is a part of dailylife, chemistry is more difficult to learn due to its conceptual structure which cannot be experienced. Students have confusion about particles such as atoms, ions and molecules and about the concepts related to the interactions between them (Boo, 1998). The current study analyzed misconceptions that students had 
about chemical bonding, one of the important topic of chemistry. Setting out from students' cognitive structures analyzed within the framework of themes, it was found that they had misconceptions about the key concepts and that their learning was below the desired level. It is pointed out in several studies in the literature that students have misconceptions about chemical bonds (Hanson, 2017; Nakhleh, 1992; Pabuçcu \& Geban, 2006). Coll and Taylor (2001) state that students of all levels have misconceptions about the metallic, ionic and covalent types of bonding. Such findings as failure to give examples for metallic bonds and giving water as an example for ionic bonds obtained in this study were supports to show that the students had misconceptions.

On examining the concept maps of the students taking part in this study, it was found that electrostatic attraction, which was belong to theme one, was not understood by some of the students. In a similar way, Atasoy, Kadayıfçı, \& Akkuş (2003) also found that students did not understand the electrostatic attraction in ionic bonds. Although the majority of the students considered ionic bonds as bonds forming between metals and metals, and covalent bonds as bonds between non-metals and nonmetals, it was found that some students had misconceptions about these concepts. In a similar vein, Birk and Kurtz (1999) state that students confuse ionic bonds with covalent bonds while Taber (1997) demonstrates that students have misconceptions about ionic bonds. On examining the students' response words to theme three, it was found that the students in the group of 10-16 cut-off point explained only the molecular compound property of covalent bonds meantime a small portion of them, the students in the group of 0-9 cut-off point, mentioned properties such as polarity, electronegativity, stability, interaction and boiling point. Dhindsa and Treagust (2014) contend that the concepts of covalent bond and polar covalent bond are closely related and that polar covalent bonding can be taught with minor modifications after covalent bonds. Burrows and Mooring (2015) state that most of the students have difficulty in setting up meaningful associations between electronegativity and polar covalent bonding.

On examining the students' cognitive structures belong to theme three, it was found that they could not fully comprehend the strong and weak interactions about the types of bonding. In a similar way, Ültay (2014) suggests that students could not fully attain conceptual learning in terms of strong and weak interactions by supporting the claim with students' misconceptions. Figure 3 shows that the students give the weak interaction response word for all types of bonding for keywords. Coll and Taylor (2001) also state that the view that electrostatic attractions keeping ionic compounds together are weak is prevalent in explaining the friability of ionic salts such as $\mathrm{NaCl}$.

It was found that no statements were made for metallic bond about theme four, and only $10 \%$ of the students gave examples for the other key words. On examining the concept maps, misconception that the bond in water was an ionic bond was found for 0-4 cut-off point. Köseoğlu and Tümay (2015) mention the misconception that there is ionic character in bonds in water molecule for such reasons as the $\mathrm{O}-\mathrm{H}$ bond could be +1 charged in hydrogen compounds and oxygen could be -2 charged. Ültay (2014) mention students' misconception that hydrogen atom forms ionic bonds by giving one electron to chloride atom for each $\mathrm{HCl}$ molecule. In contrast to this, it may be said that the students in this study did not have such a misconception.

"Chemical bonding" is a subject involving abstract concepts. On examining the students' responses to the keywords revealing their cognitive structures, it can be said that they have such concepts as atoms, molecules, ions, electrons, electrostatic attraction and sharing. In a similar way, Atasoy et al. (2003) point out that students' prior knowledge is influential in their understanding the subject of chemical bonds, which is associated with the other subjects of chemistry, and especially subjects such as atoms, orbitals, compounds, periodic table and bonds. From perspective, supporting WATs with concept maps is important in seeing how students understand the relevant concepts and the associations between concepts more clearly because this will make it possible to make evaluations reflective of students' cognitive structures. Dividing students' responses into themes in WAT evaluation and thus forming concept maps makes determining misconceptions easier. Evaluating WATs by distinguishing categories in planning the learning-teaching process is a technique which can be used in further studies for differing subjects of chemistry. This current study is thought to function as a guide to researchers and educators intending to do research on concept teaching and to determine misconceptions in the field of chemistry education. 


\section{References}

Atabek Yigit, E. (2016). Investigating cognitive structures in some basic chemistry concepts via word association test. Elementary Education Online, 15(4), 1385-1398.

Atasoy, B., Kadayıfçı, H., \& Akkuş, H. (2003). The misconception of students in the 11th grade of high schools as regards chemical bonds and the influence of the constructive approach on the elimination of it. Journal of Turkish Educational Sciences, 1(1), 61-79.

Bahar, M., Johnstone, A. H., \& Sutcliffe, R. G. (1999). Investigation of students' cognitive structure in elementary genetics through word association tests. Journal of Biological Education, 33(3), 134141.

Bahar, M., \& Özatlı, N.S. (2003). Kelime iletişim test yöntemi ile lise 1. sınıf öğrencilerinin canlıların temel bileşenleri konusundaki bilişsel yapılarının araştırılması [Investigation of cognitive structures of high school 1st grade students in the subject of basic components of living through word associate test]. Journal of Balikesir University Institute of Science and Technology, 5(2), 7585 .

Bingol, H. (2017). Evaluation of the cognitive structures of the middle school students about the concept of "Water Pollution" by using free word association test. Online Submission, 8(27), 249-258.

Birk, J. P., \& Kurtz, M. J. (1999). Effect of experience on retention and elimination of misconceptions about molecular structure and bonding. Journal of Chemical education, 76(1), 124-128.

Boo, H. K. (1998). Students' understandings of chemical bonds and the energetics of chemical reactions. Journal of Research in Science Teaching: The Official Journal of the National Association for Research in Science Teaching, 35(5), 569-581.

Burrows, N. L., \& Mooring, S. R. (2015). Using concept mapping to uncover students' knowledge structures of chemical bonding concepts. Chemistry Education Research and Practice, 16(1), 5366.

Cachapuz, A. F. C., \& Maskill, R. (1987). Detecting changes with learning in the organization of knowledge: use of word association tests to follow the learning of collision theory. International Journal of Science Education, 9(4), 491-504.

Chandrasegaran, A. L., Treagust, D. F., \& Mocerino, M. (2007). The development of a two-tier multiple-choice diagnostic instrument for evaluating secondary school students' ability to describe and explain chemical reactions using multiple levels of representation. Chemistry Education Research and Practice, 8(3), 293-307.

Coll, R. K., \& Taylor, N. (2001). Alternative conceptions of chemical bonding held by upper secondary and tertiary students. Research in Science \& Technological Education, 19(2), 171-191.

Demircioğlu, H., Vural, S., \& Demircioğlu, G. (2012). The effect of a teaching material developed based on "REACT" strategy on gifted students' achievement. Ondokuz Mayis University Journal of Education Faculty, 31(2), 101-144.

Derman, A., \& Eilks, I. (2016). Using a word association test for the assessment of high school students' cognitive structures on dissolution. Chemistry Education Research and Practice, 17(4), 902-913.

Dhindsa, H. S., \& Treagust, D. F. (2014). Prospective pedagogy for teaching chemical bonding for smart and sustainable learning. Chemistry Education Research and Practice, 15(4), 435-446.

Driver, R. (1989). Students' conceptions and the learning of science. International Journal of Science Education, 11(5), 481-490.

Ercan, F., Taşdere, A., \& Ercan, N. (2010). Observation of cognitive structure and conceptual changes through word association test. Journal of Turkish Science Education, 7(2), 136-154.

Fensham, P. (1987). Descriptions and frameworks of solutions and reactions in solutions. Research in Science Education, 17(1), 139-148. 
Garskof, B. E., \& Houston, J. P. (1963). Measurement of verbal relatedness: An idiographic approach. Psychological Review, 70(3), 277-288.

Geban, Ö., \& Bayır, G. (2000). Effect of conceptual change approach on students understanding of chemical change and conservation of matter. Hacettepe University Journal of Education, 19(19), 79-84.

Ghalkhani, M., \& Mirzaei, A. (2018). Using two-tier test to assess the fourth year students' learning and alternative conceptions in acid-base. The Online Journal of New Horizons in Education, 8(2), 122 128.

Gok Colak, F., \& Tugluk, M. N. (2017). Investigation of the cognitive structures of prospective preschool teachers on the concepts of circle, disk and annulus with the word association test. Online Submission, 8(29), 152-157.

Griffiths, A. K., \& Preston, K. R. (1992). Grade-12 students' misconceptions relating to fundamental characteristics of atoms and molecules. Journal of Research in Science Teaching, 29(6), 611-628.

Hackling, M. W., \& Garnett, P. J. (1985). Misconceptions of chemical equilibrium. The European Journal of Science Education, 7(2), 205-214.

Hand, B. (1989). Student understandings of acids and bases: A two-year study. Research in Science Education, 19(1), 133-144.

Hanson, R. (2017). Unearthing conceptions about types of chemical bonding through the use of tiered worksheets: A case study. International Journal for Cross-Disciplinary Subjects in Education, $8(2), 3112-3122$.

Harrison, A. G., \& Treagust, D. F. (2000). Learning about atoms, molecules, and chemical bonds: A case study of multiple-model use in grade 11 chemistry. Science Education, 84(3), 352-381.

Hastürk, H. G. (2017). Fen eğitiminde alternatif ölçme-değerlendirme teknikleri [Alternative measurement and evaluation techniques in science education]. In Hastürk, H.G. (Ed.), Teoriden pratiğe fen bilimleri ögretimi [Science teaching from theory to practice] (pp.498-544). Ankara: Pegem Publishing.

Johnstone, A. H., \& Moynihan, T. F. (1985). The relationship between performances in word association tests and achievement in chemistry. The European Journal of Science Education, 7(1), 57-66.

Karakuş, M., \& Karakuş, F. (2017). Examining teaching of professional concepts in teacher training and investigating students' cognitive structures regarding professional concepts. Educational Research and Reviews, 12(24), 1230-1241.

Köseoğlu, F., \& Tümay, H. (2015). Fen eğitiminde yapılandirıcllı ve yeni öğretim yöntemleri [Constructivism in science education and new teaching methods]. Ankara: Palme Publishing.

Lin, H. S., Cheng, H. J., \& Lawrenz, F. (2000). The assessment of students and teachers' understanding of gas laws. Journal of Chemical Education, 77(2), 235-238.

Luxford, C. J., \& Bretz, S. L. (2014). Development of the bonding representations inventory to identify student misconceptions about covalent and ionic bonding representations. Journal of Chemical Education, 91(3), 312-320.

Nakhleh, M. B. (1992). Why some students don't learn chemistry: Chemical misconceptions. Journal of Chemical Education, 69(3), 191-196.

Nakiboglu, C. (2008). Using word associations for assessing non-major science students' knowledge structure before and after general chemistry instruction: the case of atomic structure. Chemistry Education Research and Practice, 9(4), 309-322.

Novak, J. D., \& Gowin, D. B. (1984). Learning how to learn. Cambridge University Press. 
Osborne, R. J., \& Cosgrove, M. M. (1983). Children's conceptions of the changes of state of water. Journal of Research in Science Teaching, 20(9), 825-838.

Önal, N. (2017). Investigation of information technologies preservice teachers' cognitive perceptions towards their departments with WAT. Journal of Kirsehir Education Faculty, 18(2), 255-272.

Pabuçcu, A., \& Geban, Ö. (2006). Remediating misconceptions concerning chemical bonding through conceptual change text. Hacettepe University Journal of Education, 30(30), 184-192.

Patton, M. Q. (1990). Qualitative evaluation and research methods. SAGE Publications, inc.

Pérez, J. B., Pérez, M. B., Calatayud, M. L., García-Lopera, R., \& Sabater, J. V. (2017). Students' misconceptions on chemical bonding: a comparative study between high school and first year university students. Asian Journal of Education and e Learning, 5(01), 1-15.

Peterson, R. F., \& Treagust, D. F. (1989). Grade-12 students' misconceptions of covalent bonding and structure. Journal of Chemical Education, 66(6), 459-460.

Preece, P. E. (1976). Mapping cognitive structure: A comparison of methods. Journal of Educational Psychology, 68(1), 1-8.

Shavelson, R. J. (1973). What is the basic teaching skill? Journal of Teacher Education, 24(2), 144151.

Shavelson, R. J. (1974). Methods for examining representations of a subject-matter structure in a student's memory. Journal of Research in Science Teaching, 11(3), 231-249.

Staver, J. R., \& Lumpe, A. T. (1995). Two investigations of students' understanding of the mole concept and its use in problem solving. Journal of Research in Science Teaching, 32(2), 177-193.

Stavy, R. (1991a). Children's ideas about matter. School Science and Mathematics, 91(6), 240-244.

Stavy, R. (1991b). Using analogy to overcome misconceptions about conservation of matter. Journal of Research in Science Teaching, 28(4), 305-313.

Stewart, J. (1979). Content and cognitive structure: Critique of assessment and representation techniques used by science education researchers. Science Education, 63(3), 395-405.

Şen, Ş., \& Yılmaz, A. (2017). The development of a three-tier chemical bonding concept test. Journal of Turkish Science Education, 14(1), 110-126.

Şen, Ş., \& Yılmaz, A. (2013). A phenomenographic study on chemical bonding. Necatibey Faculty of Education Electronic Journal of Science and Mathematics Education, 7(2), 144-177.

Taber, K. (1994). Misunderstanding the ionic bond. Education in Chemistry, 31, 100-102.

Taber, K. S. (1997). Student understanding of ionic bonding: Molecular versus electrostatic thinking. School Science Review, 78(285), 85-95.

Taber, K. S., Tsaparlis, G., \& Nakiboğlu, C. (2012). Student conceptions of ionic bonding: Patterns of thinking across three European contexts. International Journal of Science Education, 34(18), 2843-2873.

Thompson, F., \& Logue, S. (2006). An exploration of common student misconceptions in science. International Education Journal, 7(4), 553-559.

Tokcan, H. (2017). Determining the Turkish world perceptions of candidate social studies teachers through word association test. Universal Journal of Educational Research, 5(8), 1386-1395.

Treagust, D. F. (1988). Development and use of diagnostic tests to evaluate students' misconceptions in science. International Journal of Science Education, 10(2), 159-169.

Tsaparlis, G., Pappa, E., \& Byers, B. (2018). Teaching and learning chemical bonding: Research-based evidence for misconceptions and conceptual difficulties experienced by students in upper 
secondary schools and the effect of an enriched text. Chemistry Education Research and Practice, 19(4), 1253-1269.

Ültay, N. (2014). Determination of $12^{\text {th }}$ grade students' conceptual knowledge about strong and weak interactions. Mehmet Akif Ersoy University Journal of Education Faculty, 1(32), 1-21.

White, R., \& Gunstone, R. (1992). Probing understanding. London and New York: The Falmer Pres.

Yıldırım, A., \& Şimşek, H. (2011). Sosyal bilimlerde nitel araştırma yöntemleri (8 ${ }^{\text {th }}$ Ed.) [Qualitative research methods in social sciences (8th Edition)]. Ankara: Seçkin Yayınc1lık.

Yücel, E. O., \& Özkan, M. (2015). Determination of secondary school students' cognitive structure, and misconception in ecological concepts through word association test. Educational Research and Reviews, 10(5), 660-674. 